\title{
HISTORICAL AND INSTITUTIONAL PERSPECTIVE BRAZIL'S NATIONAL TOURISM POLICY (1934-2014)
}

\author{
Perspectiva Histórico-Institucional da Política Nacional de Turismo no Brasil (1934-2014)
}

\author{
Gisélia Lima Carvalho *
}

\begin{abstract}
Resumo
Este artigo tem o objetivo de analisar o processo de institucionalização da atividade turística no Brasil que se dará por meio da identificação de medidas relacionadas ao turismo que ajudaram a constituir a Política Nacional de Turismo (PNT). Parte-se do princípio de que as ações, situadas em diferentes momentos históricos, formaram a ossatura da política nacional, sendo relevantes em toda análise, o que contrapõe as teses de alguns pesquisadores no Brasil ao defenderem que só houve política de fato depois de 1990. Para tanto, a estratégia pautou-se na abordagem crítica da literatura sobre política de turismo e no esforço de pesquisa documental, por meio de um levantamento da legislação pertinente do período entre 1934 e 2014 .
\end{abstract}

Palavras-chave: Política Nacional de Turismo; Planejamento; Institucionalização; Legislação.

\begin{abstract}
This paper analyzes the institutionalization of tourism in Brazil by identifying certain measures which helped constitute the country's National Tourism Policy (PNT). It is grounded on the assumption that these measures, taken at various historical moments, formed the backbone of the national policy and are relevant in any analysis of the topic. This assumption opposes theses brought forth by some Brazilian researchers, who claim that a tourism policy only existed from 1990 onwards. This study is based on a critical approach to tourism policy literature and on documentary research involving a survey of tourism-related legislation from 1934 to 2014.

Key words: National Tourism Policy; Planning; Institutionalization; Legislation.

\section{Resumen}

Este artículo tiene como objetivo analizar el proceso de institucionalización del turismo en Brasil a través de la identificación de las medidas relacionadas con el turismo que ayudaron a formar la Política Nacional de Turismo (PNT). Se parte del principio de que las acciones, ubicadas en diferentes momentos históricos, formaron la estructura de la política nacional, siendo relevante durante toda la investigación, lo que contrarresta a las tesis de algunos investigadores en Brasil que sostienen que sólo hubo política de facto después de 1990. Por lo tanto, la estrategia se basó en lo enfoque crítico de la literatura sobre la política de turismo y en el esfuerzo de investigación documental, a través de un estudio de la legislación pertinente del período entre 1934 y 2014.
\end{abstract}

Palabras-clave: Política Nacional de Turismo; Planificación; Institucionalización; Legislación.

(*) Lecturer, Doctor of the Federal Institute of Education, Science and Technology of Goiás - Rua 75, N. 46, sala S2-801, CEP: 74055-110 - Goiania (GO), Brasil. Tel: (+55 62) 32272865 - giselialimacarvalho@gmail.com 


\section{INTRODUCTION}

The backbone of the debate on Brazil's National Tourism Policy (PNT) is the State's regular status as an actor in the policy-making process. Grounded on a historical and political perspective, this paper focuses on how tourism activities became institutionalized in this country by analyzing certain tourism-related measures that went on to constitute the PNT.

Research involved a survey of tourism-related legislation from 1934 to 2014. Data was collected from the website of Brazil's lower house of Congress, or Câmara dos Deputados (http://www2.camara.leg.br/atividade-legislativa/legislacao). The survey produced 1,598 norms directly or indirectly linked to tourism. The following stage involved selecting those which had closer ties with tourism or which had influenced the country's tourism activities to some degree; this amounted to 86 texts, here referred to as greater relevance norms, and to 458 texts, here referred to as lower relevance norms. The former group, despite being the smallest of the two, comprises texts with considerable political impact in the field, which enabled tourism to become official and to be acknowledged as part of the federal government's agenda. Ranking among these texts are the ones that established official bodies, commissions, and sector funds; that formalized policies, plans, and programmes; that created the Ministry of Tourism (MTur), etc. The second group, in turn, is greater in number and comprises texts produced throughout the entire period analyzed. Although dealing with very specific issues, they helped to systematize and organize the sector by promoting regularization and inspection of tourism services and businesses, by establishing cooperation agreements and rules for the entry of foreign nationals, among other measures.

To reinforce the theoretical-methodological framework, the analysis of these texts was combined with an examination of plans and programmes launched by the federal government to develop and regulate tourism in Brazil, as well as with bibliographical research on the institutionalization of tourism in this country. The purpose was to establish a comparison with the documentary data in order to confirm it.

Such an approach broadens the possibility of understanding the development of tourism in Brazil in terms of its political and institutional scope, having state planning as its backdrop.

Preference was given to a chronological analysis of particular periods, spanning from the early days of institutional concerns about tourism activities in Brazil to the first strategies of tourism planning and PNT systematization. This analysis is followed by an overview of the future of the PNT.

\section{EARLY CONCERNS WITH TOURISM ACTIVITIES IN BRAZIL}

The first legal manifestations on tourism in Brazil date back to around 1930 and refer to very specific actions, e.g. norms for cooperation with other countries, regulation of tourism and transport businesses and of the entry of foreign nationals, incentives for events, licensing for operating leasure equipment, etc.

Using federal legislation available in the lower house of Congress website, as well as official tourism plans available in the MTur and Embratur websites, the present research produced an inventory of normative public actions spanning the period from 1934 to 2014 (Figure 1).

Careful examination of these legal instruments does not only fulfill a normative role which supports all tourism planning processes. It also broadens our understanding of tourism construction as an institutional and legal fact and as part of a national-level organic structure that affects subnational levels where tourism activities are actually performed. According to Velasco González (2007, 2011), a country's tourism policy results from the combination of various instruments (organizational, programmatic, normative or legal, financial, investigative, prospective, and communicative) that may be used jointly or alternately. 


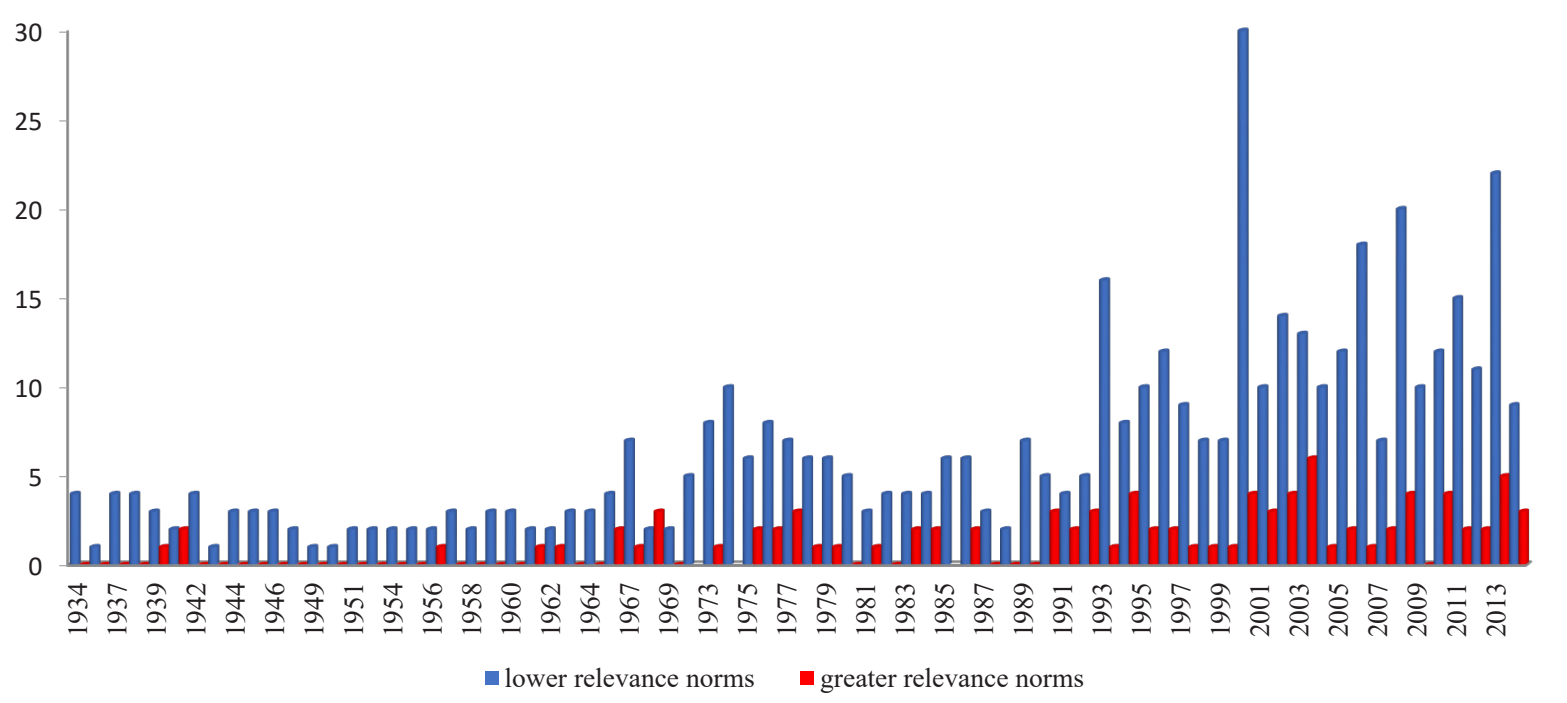

Figure 1 - Evolution of measures to institutionalize tourism activities in Brazil (1934-2014) Sources: <http://www2.camara.leg.br/atividade-legislativa/legislacao $>$, <www.turismo.gov.br $>$, <www.embratur. gov.br>.

Note: Adapted by the author.

As has been pointed out by Solha (2002), up to the 1940s tourism was still not a priority for the federal government, and the first public action on record was the creation of the Permanent Commission on Fairs and Exhibitions by Decree no. 24,163, passed on April 24, 1934 (BRASIL, 1934). Another legal document from this period was Decree-Law no. 1,915, passed on December 27, 1939 (BRASIL, 1939a), which founded the Department of Press and Propaganda (DIP), the "communicative instrument" highlighted by Velasco González $(2007,2011)$. According to Article 2 , Item b, its role consisted in "supervising, organizing, and inspecting internal and external tourism services" (BRASIL, 1939a) by means of the recently created Tourism Division (DT), the country's first "organizational instrument" (VELASCO GONZÁLEZ, 2007, 2011) for the sector. According to the DIP's guidelines, the DT was competent to

[...] promote the study, throughout the Brazilian states, of all issues pertaining to the entry, accommodation, referral, location, adaptation, and assimilation of the foreign national, by way of organizing statistics, reports, and all other sources of information required for carrying out these tasks. (BRASIL, 1939b).

These actions led to the first attempt to regulate tourism businesses, such as travel agencies, via Decree-Law no. 2,440, passed on July 23, 1940 (BRASIL, 1940); to the establishment of several cooperation agreements between countries; to the inspection of leisure equipments; to the regulation of national air transportation. The DIP was shut down in 1945 and replaced by the National Department of Information following Decree-Law no. 7,582, passed on May 25, 1945 (BRASIL, 1945). Nevertheless, the DT remained the official tourism board and its attributions echoed those formerly held by the DIP. The following years failed to produce relevant actions for the development of the sector until, in 1956, Resolution no. 57 of the lower house of Congress (BRASIL, 1956) launched a Parliamentary Investigative Commission (Comissão Parlamentar de Inquérito, or CPI) to assess tourism-related issues in Brazil. The commission should, by the end of six months, be able to diagnose such issues and propose crucial legislative measures for tourism development. These were, therefore, Brazil's first "investigative and prospective instruments", viewed by Velasco González $(2007,2011)$ as paramount for a country's tourism policy.

It becomes clear that, by that time, Brazil was already facing several problems as a result of a long period of negligence, of ongoing transformations that changed an agrarian society into an urban-industrial society, and of the growing rise of tourism flows at national and international levels. 
Yet another major act was put in place by Decree no. 44,863, passed on November 21, 1958 (BRASIL, 1958), which formalized the Brazilian Tourism Commission (Combratur) - another example of "investigative and prospective instrument" (VELASCO GONZÁLEZ, 2007, 2011) -, directly subordinated to the presidency. The commission was a consulting body responsible for coordinating activities devised to help develop domestic and foreign tourism, as well as for assessing and supervising measures pertaining to tourist movements and to the simplification and standardization of requirements and methods of information, registration, and inspection of travellers and their possessions, personal resources, transportation, and accommodation (BRASIL, 1958).

In 1962, with the ministerial restructuring launched by Decree of Ministry Council no. 534 (BRASIL, 1962), the DT was renamed Division of Tourism and Contests following the lower house's Resolution no. 57 (BRASIL, 1956). From then onwards, tourism began to draw greater attention and to pursue a higher level of professionalization, which led to the grant and creation of the first technical schools in hotel management via Decree no. 53,326, passed on December 18, 1963 (BRASIL, 1963). However, according to Araújo and César (2012), there are no clear references to tourism activities in these macroprocesses. They claim, furthermore, that the period lacked a political orientation to tourism, in addition to the sector's evident lack of a public, stable administrative structure.

\section{EARLY TOURISM PLANNING STRATEGIES IN BRAZIL}

The academic literature on tourism commonly establishes 1966 as the year in which the first planning strategies for the sector took place, thanks to Decree-Law no. 55 (BRASIL, 1966a), which represented a regulatory framework. Indeed, in the wake of the Decree-Law, the first PNT was established and the National Tourism Council (CNTur) and Embratur were created. According to Article 11, the latter was to be responsible for "incrementing the development of the tourist industry and carrying out, at national level, the guidelines set by the government" (BRASIL, 1966a). The PNT was to be designed, supervised, and managed by the CNTur, being defined as "the activity stemming from all initiatives linked to the tourist industry, whether from the private or the public sector, on its own or coordinated with others, insofar as its importance for the nation's economic development is acknowledged" (BRASIL, 1966a).

Araújo and Taschner (2012, p. 79) shed light on what this period represented for Brazilian tourism as regards the opening of lines of credit, particularly in the hospitality sector. Good examples include the General Tourism Fund (Fungetur), "designed to promote and provide resources for financing tourism-related constructions, services, and activities that are considered of interest for the development of national tourism", as well as investment funds for the North-East (Finor), for the Amazon region (Finam), and for specific sectors (Fiset).

It is safe to state that these planning strategies brought changes to the country's tourism history, having defined roles via the establishment of organizational, communicative, and financial instruments. As a result, several other legal instruments were gradually put in place, e.g. Decree no. 58,483, passed on May 23, 1966 (BRASIL, 1966b), which regulated services offered by tourism businesses; other norms addressed financial incentives and international air transportation, among other issues. In 1972, in an unprecedented move, the government allocated resources for establishing the PNT. Given the performance and credibility shown by national tourism and the boosts from the entry of foreign tourists, the following years witnessed the creation of several higher education tourism courses, the regulation of professions linked to the sector, the growing number of international cooperation agreements, the creation of investment funds to foster national tourism, and the launch of incentives to encourage foreign tourism.

Law no. 6,513, passed on December 20, 1977 (BRASIL, 1977), offered a new and important orientation for the sector by addressing special areas and places of tourist interest, as well as the 
inventory of cultural and natural assets with tourism potential - all recent issues in the political agenda of that time. However, the law was only fully regulated in 1981 via Decree no. 86,176 (BRASIL, 1981a).

It does not come as a surprise that the early 1980s - a period known as the "lost decade" - relegated the tourism sector to ostracism, a reflex of Brazil's economic crisis at that time. However, the period also saw the rise of the first actions related to ecology and culture, which remained under the spotlight in the following years despite the lack of guidelines that would support the development of tourism activities throughout the country. A major breakthrough during this decade was the promulgation of a new Federal Constitution in 1988, whose Article 24 establishes that the Union, the States, and the Federal District have the competence to legislate concurrently on: "VII - the protection of the historical, cultural, artistic, touristic, and landscape heritage; VIII - liability for damages to the environment, to consumers, to assets and rights of artistic, aesthetic, historical, touristic, and landscape value" (BRASIL, 1988). Article 180 specifically refers to tourism insofar as "the Union, the States, the Federal District, and the Municipalities are to promote and encourage tourism as a factor of social and economic development". This legal orientation was crucial in transforming tourism's political and economic scenario in Brazil from then on, for it became a guideline that conducted discourses and defined management and planning strategies.

\section{TOURISM: AN ACTIVITY REDESIGNED BY PUBLIC AUTHORITY}

During the early 1990s, some actions were devised to develop Brazil's tourism sector, but little was actually achieved given the political context - with transitions occurring within the federal government - and economic instability. Law no. 8,181, passed on March 28, 1991 (BRASIL, 1991), assigned a new name to Embratur (now Instituto Brasileiro de Turismo), a self-managed federal entity directly linked to the Ministry of Sport and Tourism whose aim consists in "supporting the creation as well as supervising the implementation of the National Tourism Policy as a factor of social and economic development". According to Cruz (2005), this law, together with regulating Decree no. 448, passed on February 14, 1992 (BRASIL, 1992), represented a benchmark in the history of Brazilian tourism because they addressed the creation of a PNT, whose aim, according to Article 1, was "the development of tourism and its consideration as a national source of income" (BRASIL, 1992). These legal documents drew attention to "the practice of tourism as a means of promoting appreciation and preservation of the country's natural and cultural heritage" as well as to "the consideration of society as the final beneficiary of touristic development" (BRASIL, 1992). In other words, to confirm the guidelines expressed in the 1988 Constitution, new issues were hence legitimized and included in the government's political agenda.

According to Cruz (2005), up to 1990 the State's participation in boosting tourism economy seldom occurred, due to several factors. Almeida (2002, p. 197) claims such a participation "was particularly concerned with hotel infrastructure". At the start of the decade a major "programmatic instrument" (VELASCO GONZÁLEZ, 2007, 2011) was launched; Plantur, or National Tourism Plan (1992-1994) proposed a change in tourism planning, whose aim was to "bring order to actions in the public sector by guiding government policies, the State's initiatives, and the use of public resources for social welfare through regional tourism development" (INSTITUTO BRASILEIRO DE TURISMO, 1992, p. 12). In view of the political instability which marked the period, the Plantur failed to be put into widespread effect, but rather set the grounds for a single, yet wide-ranging programme - the Tourism Development Programme for the North-East (Prodetur/NE). The Programme was established in 1994, when the government granted the Banco do Nordeste do Brasil S.A. (BNB) permission to hire external credit operations with the Inter-American Development Bank (IDB).

In the same year, the Special Commission for Social Tourism and the National Ecotourism Policy Guidelines were instituted. The growing social interest on ecotourism, combined with a lack of criteria, consensus, and incentives on the part of business executives, investors, and even 
government officials who acted within this sector led to the drafting of the Interministerial Directive (Ministry of Industry, Commerce, and Tourism and Ministry of Environment and Legal Amazon).

The 1996-1999 PNT was devised in 1996 with the aim to "promote and increment tourism as a source of income, employment, and socioeconomic development" (INSTITUTO BRASILEIRO DE TURISMO, 1996, p. 9). Its driving force was the National Tourism System, made up of public-private partnerships and of defining parameters for planning and carrying out actions at state and municipal levels. From it stemmed not only one of the most widely publicized actions in the government's tourism policy at that time - the National Tourism Municipalization Programme (PNMT) -, but also a redefinition of the role of all political agents, particularly those at municipal level.

The PNMT sought to boost national tourism development through decentralized public policies and consolidated planning at municipal level, grounded "on sustainability, on establishing partnerships, on mobilization and voluntary participation" (ARAÚJO; CÉSAR, 2012, p. 269). It may be viewed, therefore, as the tourism-related programme with the most significant influence on Brazilian states that had so far been launched. According to Araújo and César (2012, p. 269), the PNMT's uniqueness lay in "the simplicity of its involvement, which allowed, for instance, many local residents to join in and to become agents of tourism activities". According to Embratur's Normative Deliberation no. 417/2000 (INSTITUTO BRASILEIRO DE TURISMO, 2001), the PNMT was endorsed in 1,529 municipalities throughout Brazil. It was hoped that these cities, once submitted to the programme's assessment, would be fully prepared to form the so-called Brazilian tourist regions, the foundation for the MTur's and the new government's oncoming programme. Together with the ecotourism policy, the PNMT was one of the few programmes to include all Brazilian states whose products bore no relation with the "sun and beach" trademark, very often associated with the country's tourism. This was the case of states in the centre-west region.

In the year 2000, there were major actions in favour of environmental tourism, such as: authorization for the Union to hire an external credit operation to partially finance the Programme for Ecotourism Development in the Legal Amazon (Proecotur), via the Ministry of Environment's (MMA) Secretariat for the Coordination of the Legal Amazon; implementation of the Law of Environmental Control and Inspection Fee, or Law no. 10,165, from December 27, 2000 (BRASIL, 2000); regulation of Article 225, paragraph 1, subsections I, II, III, and VII from the Constitution, which institutes the National System of Nature Conservation Units (SNUC); issuing of Decree no. 3,683, on December 6, 2000, to alter Law no. 6,938, passed on August 31, 1981, which pertains to the National Environmental Policy, its aims and formulation and application mechanisms, as well as other issues.

The next two years saw considerable funding being allocated to north-eastern states - particularly to Ceará, Bahia, and Pernambuco - and to the Federal District through programmes Prodetur and Prodetur II. But federal-scale tourism management in Brazil undoubtedly reached its peak in 2003 with the creation of a Ministry of Tourism through Law no. 10,683, passed on May 28, 2003 (BRASIL, 2003a). The Ministry's competences pursue the full combination of instruments viewed by Velasco González $(2007,2011)$ as crucial for tourism policies.

\section{IN SEARCH FOR AN INCLUSIVE AND DECENTRALIZED TOURISM POLICY}

Notwithstanding the relevance of actions from the 1990s, the regulatory framework for structuring and planning Brazilian tourism, in short, for establishing a specific policy for the sector was, indisputably, the creation of the Ministry of Turism. On occasion of this institutional restructuring, Embratur transferred its duties to the newly-formed ministry and began to offer logistical support for carrying them out, in accordance with Decree no. 4,898, passed on November 26, 2003 (BRASIL, $2003 \mathrm{~b}$ ). At the same time, the norm which supported the making of a tourism policy was the 20032007 National Tourism Plan. In a foreword to this document, the then president Luiz Inácio Lula 
da Silva expresses the "need to create jobs, to generate foreign exchange for the country, to reduce regional inequalities, and to better income distribution" (MINISTÉRIO DO TURISMO, 2003, p. 3 ) as major challenges facing his term in office. During this period, tourism activities became

$[\ldots]$ one of the ten priorities of his administration, with the aim to face $[\ldots]$ the challenge of devising a new model of public management, one that is decentralized and participatory in order to generate foreign exchange for the country, create jobs, help reduce regional inequalities, and promote the inclusion of a wide-ranging group of social agents. (MINISTÉRIO DO TURISMO, 2005).

Decentralized management remains the operationalization strategy of the current PNT. Following this strategy, municipalities are encouraged to form consortiums which in turn produce integrated itineraries; the latter offered a set of tourist products which went on to comprise the Tourism Regionalization Programme (PRT) - Brazilian Itineraries in 2004. According to its guidelines (INSTITUTO BRASILEIRO DE TURISMO, 2013), the programme's decentralized and regionalized execution, grounded on coordinated and participatory planning, was to affect the territory's socio-economic results in a positive way. Representatives from municipal tourism agencies and associations from all 27 Brazilian states effectively took part in the early days of the programme, as well as representatives from the private and third sectors and teaching institutions. A total of 3,319 municipalities formed 219 tourist regions which make up Brazil's Tourism Regionalization Map. The strategy proved quite valid, given that the major political challenge "consisted in implementing a new model for public management - a decentralized and participatory model -, which would ultimately affect the municipality, i.e. the locus where tourism effectively takes place" (ARAÚJO; CÉSAR, 2012, p. 273).

The PRT described in the 2007-2010 National Tourism Plan clearly expresses concern for the regions' social and economic standing. It regards as relevant the act of

[...] subsidizing the structuring and qualification of these regions so that they can assume responsibility for their own development, enabling the consolidation of new itineraries as profitable and competitive tourism products in both national and international markets. For this to be achieved, it is necessary to view tourism as an economic activity capable of generating jobs, wealth, better income distribution, and social inclusion. (MINISTÉRIO DO TURISMO, 2007b).

Moreover, the plan also aimed to "promote tourism as a factor for social inclusion, by means of generating jobs and income and by including tourism activities in the consumer agenda of all Brazilians" (MINISTÉRIO DO TURISMO, 2007a, p. 16). The plans issued by the federal government reveal that tourism began to be viewed as a strategy which leads to local development and social inclusion, more so in this century. The General Tourism Law, or Law no. 11,771, was passed by Congress on September 17, 2008 (BRASIL, 2008). As is stated by the legal text, the law complies with the constitutional principles of free enterprise, decentralization, regionalization, and fair and sustainable socio-economic development (BRASIL, 2008).

Decree no. 7,381, passed on December 2, 2010 (BRASIL, 2010), regulated the General Tourism Law and set guidelines for the PNT, in addition to defining the federal government's responsibilities in planning, developing, and boosting the tourism sector. It also offers a legal standing on the PNT; it creates the National Tourism System and the Interministerial Tourism Facilitation Committee; it legislates on supporting tourism activities with Fungetur acting as a financial sponsor, as well as on registering, ranking, and inspecting tourism businesses; it establishes the general norms for applying administrative sanctions (Article 1). As is stressed by Araújo and Taschner (2012, p. 83), "with this new guideline, the aim was to reduce previous contradictions and hence facilitate the running of the sector". It becomes clear that, through this instrument, the government assigns greater rigour to the country's tourism activities, showing increased attention for planned and rational actions that are better able to instruct society. 
During the first two years of Dilma Rousseff's presidency (2011 and 2012), the lack of a new national tourism plan interrupted the recent, linear history of tourism planning in Brazil. Following guidelines set by the 2012-2015 Pluriannual Plan as well as by the Reference Document "Tourism in Brazil 2011-2014", the MTur launched the 2013-2016 National Tourism Plan (MINISTÉRIO DO TURISMO, 2013). Similarly to the two previous plans, this one has as its major aims generating job opportunities and entrepreneurship, interacting with society and encouraging its participation, as well as boosting innovation, knowledge, and regionalization.

By reviewing the historical background of tourism in Brazil and the analysis of its institutional and political dimension, new thematic orientations emerge with rising force in the management of public policies in general.

\section{WHAT IS THE FUTURE OF THE NATIONAL TOURISM POLICY?}

Going over some of the factors surrounding this issue is crucial. Firstly, the gap between the way government officials and researchers view public tourism policies should be highlighted. Hence it may be relevant to evoke policy intentionality or the politics of public policies, both of which may apply to the PNT.

Nogueira (1987) argues that only the State is capable of identifying and channelling the various interests at stake, so as to ensure the commitments made for the population's sociocultural development and life quality improvement, as well as environmental protection. Nevertheless, not every State-driven action is motivated by political goodwill or, when such a motivation exists, it is not always materialized.

As has already been stated, the literature on Brazilian tourism presents a commonplace view according to which planning strategies in the field were only made possible in the wake of Decree-Law no. 55/1966 and the PNT consolidated its position in the early 1990s (BENI, 2003; SOLHA, 2004, 2006; CRUZ, 2005; ENDRES, 2012). In fact, what we have seen is that the most incisive norms as well as the drafting of plans, programmes, and actions are more clearly linked to this period, when, as Solha (2004) claims, tourism policies became a national priority, tourism activities acquired economic relevance, and local issues began to emerge. From this one may abstract policy intentionality: there were no concerns for a broad policy. Rather, it was characterized by spontaneity, through official actions over which the government had little or no control.

Dias (2008) does not endorse this claim. By choosing not to perform a historical incision, he is less strict as to defining what a tourism policy is and when it came to exist. Hence, while affirming that a planned and established policy is generally uncommon, he points out that some specifically-aimed policies are drafted as a result of the occurrence of tourism activities. According to Dias, it is possible for a State-based tourism policy to exist without a formal document, as long as certain steps are taken, at whatever level, to guide, regulate or inspect tourism-related activities or sectors. A policy "may be incipient, badly drafted, segmented, and sectioned, but, as long as actions are being effected, a tourism policy does exist" (DIAS, 2008, p. 120).

Supporting a similar view, Lemos (2013) argues that in many developed countries where the private sector exerts greater influence in tourism-related issues, it is common for national tourism plans and strategies to present little or no legal formality, i.e. they do not come into effect by force of law nor do they demand enforcement. They are sometimes reduced to letters of intent without legal value or regulating instruments; nevertheless, they refer to specific contexts and guide government and private sector actions concerning programmes and projects to boost, support, and manage tourism. Therefore, it cannot be denied that an actual policy is in place in these countries.

The examples above confirm, from a theoretical standpoint, the fluid environment surrounding the tourism policy debate in Brazil. Ferraz (2001) helps to set limits to this debate, but supports the idea that a tourism planning process is "under way" in this country. 
Up until then, there were rules on certain aspects of tourism as an economic activity but they failed to comprise a proper, legal framework. From then onwards, several changes were introduced to this legal framework which now needs to be better suited to the development required by the tourism sector. Nevertheless, we understand there is a tourism planning process currently under way, supported by a specific legal framework and influenced by more general but related frameworks. (FERRAZ, 2001, p. 27, italics mine).

I believe the importance of tourism's institutionalization process should not be overlooked, given that it underlies all public policies. Policies require a legal apparatus through which relevant measures may come to subsidize and instrumentalize the State's role in tourism planning and in the drafting of future national policies.

The enactment of rules for tourism since the Vargas Era has led to the development of tourism activities and constructed an agenda of sectoral priorities. The so-called greater relevance norms were frequent along the historical period analyzed in this paper, although not as much as the lower relevance norms. They include texts which establish: the creation of official government departments responsible for tourism planning; the drafting of implementation programmes and projects; the creation of investment funds and tax incentives for tourism businesses; the forming of commissions to examine problems in Brazilian tourism; the setting of long-term tourism guidelines and plans, etc.

Conversely, several other legal instruments of lesser impact were gradually launched throughout the political formation of tourism in Brazil. With every act, successive governments instrumentalized and constructed the backbone of tourism policy, thus contributing to its regulation nationwide. According to Araújo and César's (2012, p. 258) analysis of the development of Brazilian tourism's political and institutional framework, such policy "has shown itself as a constantly changing system, but it is noteworthy that such a movement is not linear: it represents drawbacks and advancements that are typical of this kind of transition". In fact, the conduction of the country's tourism policy changed course following the guidelines expressed in the 1988 Constitution, leading to an institutionalization of national planning that came into effect with the first Pluriannual Planning (1991-1995). The effects of this process clearly reflected in all social segments. Cruz (2006) argues that changes in Brazilian politics, inherent in the transition from old to new paradigms, extended to tourism public policies. The extent of such changes included, among other factors, decentralization and the participation of other actors at state and municipal levels. Therefore, tourism policy no longer focused solely on the vague national context and began to consider regional and local levels; it stopped pursuing development at all costs, including the exploitation of nature and small communities, and began to consider the generation of jobs and revenues and of a sustainable development model. Obviously different territories are affected differently, depending on the organizational level of local actors.

The most popular approach to the issue in Brazil's tourism literature views the Itamar Franco government in the early 1990 s as the actual turning point for the history of government planning in Brazil and its effects on tourism policy. I believe that the turn of the century introduced new and relevant issues that deeply affected society and that became an institutional mark in the tourism sector. Issues that were already addressed by politics, albeit superficially in general - such as the environment, society, and culture -, began to be viewed in terms of their specificities; examples include challenges facing social responsibility, the control and inspection of sexual exploitation and child and youth trafficking, as well as accessible tourism for people with special needs. In the field of culture, a fine example of initiative that affected tourism was the National Culture Plan. It shows a new intent on the part of public policies in Brazil, one that has had an impact on tourism and on the acknowledgement that tourist planning needs to overcome its own sectoral barrier. This process has certainly ensured a policy that is wider in scope and more attentive to the dilemmas of society. 


\section{FINAL CONSIDERATIONS}

It is hoped that the processes described in this paper promote a fuller understanding of the tourism scenario in Brazil as regards its political and institutional dimension. Among these processes is the one concerning the establishment of the National Tourism Policy, or PNT. Despite the widespread notion that Brazil's tourism policy only existed after 1990, I have sought to demonstrate, by analyzing the historical and institutional framework available, that with every instrument, public action, and planning or investment effort launched by the State, the PNT as we know it gradually developed. In other words, the tourism policy results from a surplus of actions over time and from the work of several public and private actors.

The considerable change that took place over the course of the period under analysis is the planning model that followed the 1988 Constitution and extended to all areas of society, thus redefining actors' roles and performance levels. In the tourism sector, the National Tourism System implemented decentralized management of tourism activities, brought together and optimized interscale relations - which called for greater involvement at municipal level - , as well as reestablished parameters for public policy planning, relevance, and inclusion, whether from a spatial perspective - by devising a plan to include all Brazilian regions - or from a socio-economic one - by welcoming new turists or by increasing local job and income opportunities.

It must be conceded that Brazil's planning process has been conducting, since the 1930s, a different, broader policy in the 21 st century, a policy which strives to boost tourism activities in their cultural, social, economic, environmental, and political aspects, as well as the participation of local actors, particularly after the 2003-2007 PNT. However, it must be stressed that such a planning model to cover the entire tourism system has not yet consolidated itself in other parts of the world and especially not in Brazil. Given this premise, another one is brought to the fore: despite the decentralization processes greatly advertised by official tourism plans, subnational scales are still called upon to rise as geographic spaces that are politically privileged and particularly interested in such a planning model. Souza (2013) believes that the local scale should be a space in which to exercise autonomy. In other words, actions like taking part in creating institutionality and helping to establish and carry out an agenda of interests must make up the formation process of local-scale political autonomy and its integration with national politics.

\section{BIBLIOGRAPHIC REFERENCE}

ALMEIDA, Maria G. de. Políticas públicas e o delineamento do espaço turístico goiano. In: (Org.). Abordagens geográficas de Goiás. Goiânia: Ed. UFG, 2002. p. 197-222.

ARAÚJO, Cíntia M.; TASCHNER, Gisela. Turismo e políticas públicas. In: BENI, Mario C. (Org.). Turismo: planejamento estratégico e capacidade de gestão - desenvolvimento regional, rede de produção e clusters. Barueri, SP: Manole, 2012. p. 10-24.

ARAÚJO, Cíntia M.; CÉSAR, Pedro de A. B. Dimensão político-institucional do turismo no Brasil. In. BENI, Mario C. (Org.). Turismo: planejamento estratégico e capacidade de gestão - desenvolvimento regional, rede de produção e clusters. Barueri, SP: Manole, 2012. p. 257-282.

BANCO DO NORDESTE. Prodetur/NE I: ampliando e modernizando a infraestrutura turística do Nordeste do Brasil. [20--]. Disponível em: $<$ http://www.bnb.gov.br/objetivos1>.

BENI, Mario C. A política do turismo. In: TRIGO, Luiz G. G. et al. (Org.). Turismo: como aprender, como ensinar. São Paulo: Senac, 2003. p. 177-202.

BRASIL. Decreto no 24.163, de 24 de Abril de 1934 (BRASIL, 1934). Institui a Comissão Permanente de Exposições e Feiras e dá outras providências. Legislação, Brasília, DF, 1934. Disponível em: <http://www2. camara.leg.br/legin/fed/decret/1930-1939/decreto-24163-24-abril-1934-505054-norma-pe.html>

BRASIL. Decreto-Lei no 1.915, de 27 de dezembro de 1939. Cria o Departamento de Imprensa e Propaganda 
e dá outras providências. Legislação, Brasília, DF, 1939a. Disponível em: <http://www2.camara.leg.br/legin/ fed/declei/1930-1939/decreto-lei-1915-27-dezembro-1939-411881-norma-pe.html>.

BRASIL. Decreto n $\mathbf{n}^{\mathbf{5 . 0 7 7}}$, de 29 de dezembro de 1939. Aprova o regimento do Departamento de Imprensa e Propaganda (D.I.P.). Legislação, Brasília, DF, 1939b. Disponível em: < http://www2.camara.leg.br/legin/ fed/decret/1930-1939/decreto-5077-29-dezembro-1939-345395-norma-pe.html>.

BRASIL. Decreto-Lei $\mathbf{n}^{\mathbf{0}}$ 2.440, de 23 de julho de 1940. Regula as atividades das empresas e agências de viagens e turismo. Legislação, Brasília, DF, 1940. Disponível em: <http://www2.camara.leg.br/legin/fed/ declei/1940-1949/decreto-lei-2440-23-julho-1940-412448-norma-pe.html>.

BRASIL. Decreto-Lei no 7.582, de 25 de maio de 1945. Extingue o Departamento de Imprensa e Propaganda e cria o Departamento Nacional de Informações. Legislação, Brasília, DF, 1945. Disponível em: <http:// www2.camara.leg.br/legin/fed/declei/1940-1949/decreto-lei-7582-25-maio-1945-417383-norma-pe.html>.

BRASIL. Resolução da Câmara dos Deputados no 57, de 1956. Constitui uma Comissão Parlamentar de Inquérito para estudar os problemas de turismo no Brasil. Legislação, Brasília, DF, 1956. Disponível em: <http://www2.camara.leg.br/legin/fed/rescad/1950-1959/resolucaodacamaradosdeputados-57-21-marco-1956-319770-norma-pl.html>.

BRASIL. Decreto $\mathbf{n}^{\mathbf{0}} \mathbf{4 4 . 8 6 3}$, de 21 de novembro de 1958. Institui a Comissão Brasileira de Turismo. (COMBRATUR). Legislação, Brasília, DF, 1958. Disponível em: <http://www2.camara.leg.br/legin/fed/ decret/1950-1959/decreto-44863-21-novembro-1958-383896-norma-pe.html>.

BRASIL. Decreto do Conselho de Ministros no 534, de 23 de janeiro de 1962. Aprova o Regimento da Secretaria do Comércio do Ministério da Indústria e do Comércio. Legislação, Brasília, DF, 1962. Disponível em: <http://www2.camara.leg.br/legin/fed/decmin/1960-1969/decretodoconselhodeministros-534-23-janeiro-1962-355763-retificacao-40375-pe.html>.

BRASIL. Decreto ${ }^{0} \mathbf{5 3 . 3 2 6}$, de 18 de dezembro de 1963. Autoriza a criação de escolas técnicas de hotelaria e dá outras providências. Legislação, Brasília, DF, 1963. Disponível em: <http://www2.camara.leg.br/legin/ fed/decret/1960-1969/decreto-53326-18-dezembro-1963-393398-norma-pe.htm>.

BRASIL. Decreto-Lei $\mathbf{n}^{\circ}$ 55, de 18 de novembro de 1966. Define a política nacional de turismo, cria o Conselho Nacional de Turismo e a Empresa Brasileira de Turismo, e dá outras providências. Legislação, Brasília, DF, 1966a. Disponível em: <http://www2.camara.leg.br/legin/fed/declei/1960-1969/decreto-lei-55-18-novembro-1966-371224-norma-pe.html>.

BRASIL. Decreto $\mathbf{n}^{0} \mathbf{5 8 . 4 8 3}$, de 23 de maio de 1966. Dispõe sobre os serviços de empresas de turismo, revoga o Decreto número 56.303-65 e dá outras providências. Legislação, Brasília, DF, 1966b. Disponível em: <http://www2.camara.leg.br/legin/fed/decret/1960-1969/decreto-58483-23-maio-1966-399010-normape.html $>$.

BRASIL. Decreto-Lei no 1.191, de 27 de outubro de 1971. Dispõe sobre os incentivos fiscais ao turismo e dá outras providências. Legislação, Brasília, DF, 1971. Disponível em: <http://www2.camara.leg.br/legin/ fed/declei/1970-1979/decreto-lei-1191-27-outubro-1971-375494-norma-pe.html>.

BRASIL. Decreto-Lei no 1.376, de 12 de dezembro de 1974. Dispõe sobre a criação de Fundos de Investimento. Legislação, Brasília, DF, 1974. Disponível em: <http://www2.camara.leg.br/legin/fed/declei/1970-1979/ decreto-lei-1376-12-dezembro-1974-375617-publicacaooriginal-1-pe.html>.

BRASIL. Lei $\mathbf{n}^{\mathbf{0}} \mathbf{6 . 5 1 3}$, de 20 de dezembro de 1977. Dispõe sobre a criação de Áreas Especiais e de Locais de Interesse Turístico. Legislação, Brasília, DF, 1977. Disponível em: <http://www2.camara.leg.br/legin/ fed/lei/1970-1979/lei-6513-20-dezembro-1977-366517-norma-pl.html>.

BRASIL. Decreto $\mathbf{n}^{\mathbf{0}} \mathbf{8 6 . 1 7 6}$, de 6 de julho de 1981. Regulamenta a Lei ${ }^{\circ}$ 6.513, de 20 de dezembro de 1977 , que dispõe sobre a criação de Áreas Especiais e de Locais de Interesse Turístico e dá outras providências. Legislação, Brasília, DF, 1981a. Disponível em: <http://www2.camara.leg.br/legin/fed/decret/1980-1987/ decreto-86176-6-julho-1981-435843-norma-pe.html>.

BRASIL. Secretaria de Planejamento. III Plano Nacional de Desenvolvimento - PND. Brasília, DF, 1981 b. BRASIL. Constituição Federal (1988). Brasília, DF: Casa Civil, 1988. Disponível em: <http://www.planalto. gov.br/ccivil_03/constituicao/constituicaocompilado.htm>. 
BRASIL. Lei nº 8.181, de 28 de março de 1991. Dá nova denominação à Empresa Brasileira de Turismo - EMBRATUR, e dá outras providências. Legislação, Brasília, DF, 1991. Disponível em: <http://www2. camara.leg.br/legin/fed/lei/1991/lei-8181-28-marco-1991-363895-norma-pl.html>.

BRASIL. Decreto no 448, de 14 de fevereiro de 1992. Regulamenta dispositivos da Lei ${ }^{\circ}$ 8.181, de 28 de março de 1991, dispõe sobre a Política Nacional de Turismo e dá outras providências. Legislação, Brasília, DF, 1992. Disponível em: <http://www2.camara.leg.br/legin/fed/decret/1992/decreto-448-14-fevereiro-1992-343147-norma-pe.html>.

BRASIL. Lei $\mathbf{n}^{\mathbf{0}} \mathbf{1 0 . 1 6 5}$, de 27 de dezembro de 2000. Altera a Lei $\mathrm{n}^{\circ}$ 6.938, de 31 de agosto de 1981, que dispõe sobre a Política Nacional do Meio Ambiente, seus fins e mecanismos de formulação e aplicação, e dá outras providências. Legislação, Brasília, DF, 2000. Disponível em: <http://www2.camara.leg.br/legin/ fed/lei/2000/lei-10165-27-dezembro-2000-353895-norma-pl.html>.

BRASIL. Lei $\mathbf{n}^{\mathbf{0}} \mathbf{1 0 . 6 8 3}$, de 28 de maio de 2003. Dispõe sobre a organização da Presidência da República e dos Ministérios, e dá outras providências. Legislação, Brasília, DF, 2003a. Disponível em: < http://www2. camara.leg.br/legin/fed/lei/2003/lei-10683-28-maio-2003-496772-norma-pl.html>.

BRASIL. Decreto $\mathbf{n}^{\mathbf{0}} \mathbf{4 . 8 9 8}$, de 26 de novembro de 2003. Transfere competências da EMBRATUR - Instituto Brasileiro de Turismo para o Ministério do Turismo, e dá outras providências. Brasília, DF, $2003 \mathrm{~b}$. Disponível em: <http:/www.planalto.gov.br/ccivil_03/decreto/2003/d4898.htm>.

BRASIL. Lei $\mathbf{n}^{\mathbf{0}}$ 11.771, de 17 de setembro de 2008. Dispõe sobre a Política Nacional de Turismo, define as atribuições do Governo Federal no planejamento, desenvolvimento e estímulo ao setor turístico, revoga a Lei $\mathrm{n}^{\mathrm{o}} 6.505$, de 13 de dezembro de 1977, o Decreto-Lei n n $^{\circ} .294$, de 21 de novembro de 1986, e dispositivos da Lei $\mathrm{n}^{\circ} 8.181$, de 28 de março de 1991; e dá outras providências. Legislação, Brasília, DF, 2008. Disponível em: <http://www2.camara.leg.br/legin/fed/lei/2008/lei-11771-17-setembro-2008-580751-norma-pl.html>.

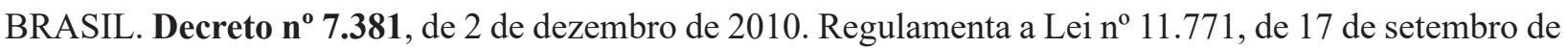
2008, que dispõe sobre a Política Nacional de Turismo, define as atribuições do Governo Federal no planejamento, desenvolvimento e estímulo ao setor turístico, e dá outras providências. Legislação, Brasília, DF, 2010. Disponível em: <http://www2.camara.leg.br/legin/fed/decret/2010/decreto-7381-2-dezembro-2010-609612-norma-pe.html>.

CRUZ, Rita de Cássia A. Política de turismo e território. São Paulo: Contexto, 2000.

CRUZ, Rita de Cássia A. Políticas públicas de turismo no Brasil: território usado, território negligenciado. Geosul, Florianópolis, v. 20, n. 40, p. 27-43, jul./dez. 2005.

CRUZ, Rita de Cássia A. Planejamento governamental do turismo: convergências e contradições na produção do espaço. In: LEMOS, Amalia I. G. de; ARROYO, Mónica; SILVEIRA, María Laura (Org.). América Latina: cidade, campo e turismo. São Paulo: CLACSO/USP, 2006.

DIAS, Reinaldo. Planejamento do turismo. São Paulo: Atlas, 2008.

ENDRES, Ana V. As políticas de turismo e os novos arranjos institucionais na Paraíba/Brasil. 2012. 330 f. Tese (Doutorado em Sociologia Política) - Centro de Filosofia e Ciências Humanas, Universidade Federal de Santa Catarina, Florianópolis, 2012.

FERRAZ, Joandre A. Regime jurídico do turismo. 2. ed. atual. ampl. Bauru, SP: EDIPRO, 2001.

INSTITUTO BRASILEIRO DE TURISMO (EMBRATUR). PLANTUR - Plano Nacional de Turismo: 1992-1994. Brasília, DF, 1992. Mimeografado.

INSTITUTO BRASILEIRO DE TURISMO (EMBRATUR). Política Nacional de Turismo: diretrizes e programas 1996-1999. Brasília, DF, 1996.

INSTITUTO BRASILEIRO DE TURISMO (EMBRATUR). Programa de Regionalização do Turismo: diretrizes. Brasília, DF, 2013.

LEMOS, Clara C. Planejamento do turismo em âmbito federal: uma análise dos instrumentos utilizados e dos investimentos no setor. Revista de Administração Pública, Rio de Janeiro, v. 47, n. 6, p. 14011427, dez. 2013. Disponível em: < <http://www.scielo.br/scielo.php?script=sci_arttext\&pid=S0034-76122013000600004\&lng=en\&nrm=iso>. Acesso em: 25 June 2015.

MINISTÉRIO DO TURISMO (MTUR). Plano Nacional de Turismo 2003/2007. Brasília, DF, 2003. 
MINISTÉRIO DO TURISMO (MTUR). $7^{\circ}$ Relatório de atividades. Brasília, DF, mar. 2005.

MINISTÉRIO DO TURISMO (MTUR). Plano Nacional de Turismo 2007/2010: uma viagem de inclusão. Brasília, DF, 2007a.

MINISTÉRIO DO TURISMO (MTUR). Módulo operacional 2: mobilização. Brasília, DF, $2007 \mathrm{~b}$.

MINISTÉRIO DO TURISMO (MTUR). Plano Nacional de Turismo 2013/2016: o turismo fazendo muito mais pelo Brasil. Brasília, DF, 2013.

NOGUEIRA, Mário G. O papel do turismo no desenvolvimento econômico e social do Brasil. Revista de Administração Pública, Rio de Janeiro, v. 21, n. 2, p. 37-54, abr./jun. 1987. Disponível em: <http://bibliotecadigital.fgv.br/ojs/index.php/rap/article/view/9772/8795>.

SOLHA, Karina T. Evolução do Turismo no Brasil. In: REJOWSKI, M. Turismo no percurso do tempo. São Paulo: Aleph, 2002.

SOLHA, Karina T. Órgãos públicos estaduais e o desenvolvimento do turismo no Brasil. 2004. 168 f. Tese (Doutorado em Relações Públicas, Propaganda e Turismo) - Escola de Comunicação e Artes, Universidade de São Paulo, São Paulo, 2004.

SOLHA, Karina T. Política de turismo: desenvolvimento e implementação. In: RUSCHMANN, Doris; SOLHA, Karina T. (Org.) Planejamento turístico. Barueri, 2006.

SOUZA, M. L. de. Os conceitos fundamentais da pesquisa sócio-espacial. Rio de Janeiro: Bertrand Brasil, 2013.

VELASCO GONZÁLEZ, María. La política turística: una arena de acción autónoma. Cuadernos de Turismo, n. 27, p. 953-969, 2011.

VELASCO GONZÁLEZ, María. Distintos instrumentos para um mismo fin. Los ins-trumentos de las políticas públicas como herramienta para el análisis. In: Congreso Español de Ciencia Política y de la Administración, 8., 2007, Valencia. Não publicado.

Submitted january 2016

Accepted february 2016 